\title{
OPORTUNIDADES DE TRATAMIENTO EN CORONAVIRUS (SARS-COV-2)
}

TREATMENT OPPORTUNITIES IN CORONAVIRUS (SARS-COV-2)

\section{Rodrigo ESPINOZA ${ }^{1}$}

${ }^{1}$ Universidad Nacional de Asunción, Facultad Politécnica, San Lorenzo, Paraguay.

Cómo citar este artículo: Espinoza R. Oportunidades de tratamiento en coronavirus (SARS-CoV-2). Med. clín. soc. 2019;3(3):102-103.

\section{Estimado Editor,}

Quisiera aprovechar este espacio para compartir actualizaciones sobre desarrollos de posibles tratamientos a la enfermedad causada por el coronavirus SARS-CoV-2, según lo descrito por Antonio Regalado en el MIT Technology Review (1). El virus SARS-CoV-2 ha infectado a más de 70000 personas en solamente China central, su expansión a otros países como Corea del Sur e Italia, y hasta a otros continentes, Ilegando a los Estados Unidos, está al límite de ser considerada una pandemia. De ser así, miles de millones de personas necesitarán alguna droga o vacuna para tratarse (2). Estas son algunas de las investigaciones de tratamientos más prometedores hasta el momento:

\section{Bloqueadores de virus}

La droga inyectable "remdesivir", de Gilead Sciences, es un antiviral de amplio espectro, a la cual se le tiene mucho optimismo. Ésta, forma un nucleótido disfuncional que el virus necesita para replicarse, evitando así que se multiplique. En enero del corriente año, ya se le ha inyectado a un paciente de 35 años de edad en los Estados Unidos, quien luego se ha recuperado de la infección. El Instituto Nacional de Salud (NIH, por sus siglas en inglés) está realizando un estudio con pacientes infectados, quienes de momento se encuentran en cuarentena.

\section{Vacunas}

El clásico mecanismo de las vacunas es inyectar un antígeno (pequeña porción) del virus para entrenar al sistema inmunológico en caso de que se encuentre con la infección real. A la larga es el mejor mecanismo preventivo, pero su desarrollo tarda (en el mejor de los casos) 3 a 4 años. La empresa encargada del desarrollo de la vacuna, Sanofi, está produciendo antígenos virales en células de insectos, siendo esta una técnica biotecnológica más rentable que la clásica, la cual utiliza huevos de gallina (sería impensable conseguir tantos huevos en el caso de una pandemia).

\section{Vacunas "más rápidas"}

Existen tecnologías modernas de vacunas, llamadas vacunas de ADN, ARN o plásmidos, en las que se inyectan pequeñas porciones del material genético del virus al torrente sanguíneo. Así, el mismo cuerpo produce los antígenos virales, y luego continúa con el mismo mecanismo que una vacuna normal. Lo malo de este tipo de vacunas es que no tienen mucho éxito (todavía) 
en el campo biomédico, pero son mucho más rápidos de producir. Es más, la empresa Modern Therapeutics ya ha enviado algunas dosis al $\mathrm{NIH}$, donde se inyectará a voluntarios para probar su eficacia.

Plasma de sobrevivientes

Una persona que se recupera de una infección tiene su sangre colmada de anticuerpos contra el virus. Se ha probado que una transfusión de plasma sanguíneo de sobrevivientes al virus a un infectado, puede salvarle la vida. Aunque no siempre es eficiente, más de 27000 personas están registradas como "recuperadas", y dispuestas a donar su suero. Tal es así que doctores en Shanghai ya están aplicando este método. Además del incesante esfuerzo de producir nuevas drogas o tecnologías para combatir al SARS-CoV-2, se están buscando utilizar drogas ya existentes, tales como:

\section{Cloroquina}

Algunos científicos sostienen que la antigua droga contra la malaria funciona contra este coronavirus. Esto no se ha probado aún, pero como la droga ya existe, y sus estudios son baratos, se tomó en consideración en China. Los laboratorios donde se han llevado a cabo los tests iniciales sugieren que ésta droga, descubierta en 1934, puede ser muy efectiva.

\section{Drogas contra VIH}

En el caso de pacientes que necesitan con urgencia un tratamiento, algunos doctores en China recurrieron a la utilización de drogas que tenían "a mano". De tal manera, empezaron a utilizar varios medicamentos que se utilizan contra HIV, tales como lopinavir o ritonavir. Los resultados por el momento son desalentadores, pero tienen planeado seguir probando con otras drogas (Truvada, por ejemplo), que son más bien preventivas contra el virus HIV que, al igual que SARS-CoV-2, es un retrovirus.

\section{CONFLICTOS DE INTERÉS Y FUENTE DE FINANCIACIÓN}

El autor declara no poseer conflictos de interés. Fuente de financiación: ninguna.

\section{REFERENCIAS BIBLIOGRÁFICAS}

1. Regalado A. What are the best coronavirus treatments? [Internet]. MIT Technology Review. [citado el 26 de febrero de 2020]. Disponible en: https://www.technologyreview.com/s/615284/what-are-the-best-coronavirustreatments/

2. Huang C, Wang Y, Li X, Ren L, Zhao J, Hu Y, et al. Clinical features of patients infected with 2019 novel coronavirus in Wuhan, China. The Lancet. 2020;395(10223):497506. https://dx.doi.org/10.1016/S0140-6736(20)30183-5 